\title{
Memory and a Hard Place: Revisiting Central Havana
}

\author{
Marivic Wyndham, University of Technology Sydney, and Peter Read, University \\ of Sydney
}

This is the story of how two men remember the ruined precinct of Central Havana. One left in 1959 and did not return for 32 years. The other has never left the island of Cuba. Their names are Manolo and Raúl.

How do these two men of similar age, he the dispossessed, he the possessor, remember their city of memory? Whom and what do they exclude from the myth-making of memory and by what processes? This paper follows the return of the two men to the area of the city which meant most to them as young men: Central Havana, then and now the hub of the capital's social and commercial life. Raúl has remained in the city for half a century, but until the invitation of the authors to show him the sites of his earlier life, had not entered Central Havana for some years. The second, Manolo, returned from exile in Miami to Central Havana in 1991 to make a clandestine film, La Habana de hoy $y$ de siempre, about the city that he once loved, and lost. ${ }^{1}$

Raúl is a strong and fit sixty-five year old retired dock worker. He lives with his wife

\footnotetext{
${ }^{1}$ Rather than in the context of Cuban film production, the film is best assessed within the international theme of exiles or others returning to a significant site after traumatic experience and departure. Parallel documentaries are, in Australia, Hellfire Pass (Chase 1987), in which former soldiers return to the Burma Railway after many years, and in Chile, Carmen Castillo’s Calle Santa Fe (2007), in which Castillo returns to the Santiago street where she was wounded, and her husband killed, by Pinochet's forces. Like most other films in the genre, these documentaries focus on the emotions of those who return, including nostalgia, alienation, unfamiliarity with present time, and an attempted spiritual repossession of the site. The field has even wider literary roots, including, in Australia, Andrew Riemer's Inside Outside (1992), in which Riemer returns to his war-time home in Budapest, and in Cuba, the essay by Manuel Bretos with which this article concludes.
} 
María in a modest flat in the tourist suburb of La Rampa. Most evenings Raúl and María will be found at the home of their daughter, her husband and their grandson. María will be there by three to begin to prepare the evening meal by picking the stones out of the rice, Raúl will come by at about five. They’ll cook dinner together chatting with the family over a rum or two, and after dinner, dominoes. In a noisy, loving household, Raúl seems to be the only one sometimes prepared to say no to his adored grandson.

At the age of seventeen, in about 1953, Raúl left the hard but rewarding life of vegetables, pigs and donkeys of his family farm for the excitement of the city. In the smart shopping centre of Central Havana he watched the chauffeurs drop off the rich families outside the modern department stores like El Encanto and Fin de Siglo, and return for them, and their parcels, in a couple of hours. But he did not feel alienated. He had no doubt that, as a young man, the city was his also. While the rich were inside Fin de Siglo, he and his friends were in Woolworths (better known as Ten Cent) nearby. In Central Havana was street life, the brand new Rex Cinema, the French and Spanish speciality shops, the corner cafes, bustling crowds, the dressing up, the self-confidence of the young Cuban male. Then came the revolution.

Manolo was born at about the same time as Raúl. He lived and grew up in the city in much more wealthy circumstances. A well known Florida television identity in the 1990s, he is part of the large Cuban American exile community that since that 1960s has made Miami its home-away-from-home. Life in Havana of the mid 1950s offered much to young men like him: education at one of the best schools, law, medicine or engineering in the university. His life as a young man was Saturday tennis and dinner at the family's exclusive club, church on Sunday, an honoured place in the family firm, a modern car, a house in the country, a limitless future. After an absence of three decades, he reminisced 'How much we enjoyed sitting on the sea wall, looking at the unique sunset of Cuba, or getting wet as winter approached and the waves broke.' Then came the revolution.

So in the 1960s his city slipped from reality to memory. In the 1970s his Havana was no longer a yearning but a phantom. By the 1980s his fantasy city, like the castle of the sleeping beauty, was interwoven in his mind with metaphorical briars. The best people had left her, the remainder were unable to waken. The thorny spikes imprisoned its 
dream people, who awaited the touch and the kiss of the handsome prince who would one day return to reclaim the beautiful woman-city who had promised, then denied, so much. Emotionally Manolo’s Central Havana remained entrapped in the memory of his group of exiles, young, male and rich, who had become her self-appointed custodians. Almost always they mourned her in the trope of a lost love.

Raúl's city was not frozen but airy. He lived in her and took part in her activities. Not likely to inherit anything in the city before the revolution, he did not do so afterwards. By 1963 he was drafted into a brigade of the unskilled labour force. For some years he was optimistic; he enjoyed the sense of purpose while his work brigade constructed its own apartment block. Daily he walked or cycled the five kilometres to the docks to the two-storey wooden buildings lining the waterfront. By 1980 he realised that the docklands of the port of Havana would be his employment for life.

His city continued to change, but for the worse. Nurturing a sense of the solid elegance of Spanish colonial architecture, Raúl was distressed when by the end of the sixties, the dock buildings were looking dingy, their paint flaking and the cement crumbling. By 1970 buildings throughout his city began to close or were abandoned. Some even collapsed. It was not the fault of the revolution, he reflected; preservation was hardly possible under the strictures of the American embargo. Yet his aesthetic sense was offended. While Manolo’s woman-city was enchanted and immobilised, Raúl's was real, but ageing.

In 2000 he was a pensioner, but out of necessity still working. Intrigued by history, he held a large collection of 'forties and 'fifties newspapers which he was delighted to show and discuss with the visitor. Listening to short-wave radio at night, he picked up Spanish language programs from Latin America and Europe and was well informed on world events. Short, solid, with thinning hair and commonly in sandals, shorts and a Tshirt, he seemed happiest when visiting his brother's small farm an hour from Havana. Unquestionably his revolution had soured. He began to denounce the pervasive network of neighbourhood spies. He condemned indignities at the hands of the police: more than once he was forced to empty his lunch box on the streets to demonstrate to the militia, and to any passer-by, that he was no black marketeer or saboteur. He conceded, in private conversation, a deep but helpless anger held in check only with difficulty, that 
the young people, especially the men, were in 2000 no more able to control their destinies than the young men drafted into work brigades just after the revolution. For in 1959 Raúl was a young man such as they. So was Manolo.

When the authors asked Raúl to show us his personal, pre-revolutionary Havana, he began mentally sketching the route through the city of his youth. He wanted to demonstrate his own places of memory, where he had hung out, bought ice cream, ridden his bike, met his friends, talked to girls and bought the suit he was married in. What is known to tourists as Old Havana hardly touched him, nor the tourists' restaurants, nor their modern 'photo opportunity' sites, nor the Spanish fortress El Morro, nor the old churches, nor his own suburb. Central Havana was his immediate choice, the city of excitement of his youth.

Central Havana is in reality two distinct areas. Choose a thoroughfare one or two streets away from the famous beachfront avenue El Malecón, walk downhill and west from the hotel Habana Libre and the city becomes suddenly poorer: fewer tourists, more abandoned or destroyed buildings, fewer Cubans selling cigars and taxi rides, fewer hustlers, more pedestrians. Tourist guide books recommend very few places to visit. The streets are too narrow for their buses. Neptuno, San Rafael, Canongo, Escobar, Lealtad, Perseverancia: these streets are close to El Malecón, yet they could almost be in another city. For this once modernist precinct has aged badly. Eighteenth-century Spanish Colonial architecture can still look stately after decades of neglect, but the architects of the post World War II downtown of Central Havana used the latest postwar materials of plastic, plate glass, paint and tile. Such materials un-maintained for forty or fifty years look ugly and deteriorated. Move further west through Lealtad and Perseverancia towards El Prado: quite suddenly, the streetscape improves. After not much more than a kilometre, the pedestrian arrives in the Avenida del Prado itself, its diplomatic-plated Mercedes, fine hotels, scammers, hustlers, uniforms, museums, restaurants, imposing churches, buildings in process of elegant and rapid restoration by the City Historian, the powerful official charged with the ultimate restoration of the entire city. Glance east again: the streets of Central Havana are there, just out of sight, still thronged with the city's poor.

Manolo understood the difference too, because in 1991, he returned to Havana 
clandestinely. He was to make a film about the city which would never again be the playground of the rich young men of 1959, but which to that generation remained emotionally theirs, and only theirs, forever. At the moment when the consequences of the Russian withdrawal, after the collapse of the Soviet camp in the late 1980s, touched their most painful low point of poverty and despair, he secreted a video camera aboard a plane from Miami to Havana, then into a hire car, to investigate what had become of the city of ideal memory. The result was a 60 minute video shown on Miami television, $L a$ Habana de hoy y de siempre, (Havana Now As Always). It marked an emotional reunion with the city from which he had been absent for thirty years, and the city which his former countryman Raúl had never left. A personal visual testimony, rather than a commercial production, it speaks to and for the many Manolos who have never returned to their island.

Manolo’s film journey begins as, about to leave Miami for Havana, he approaches the camera and stands before a Spanish colonial, Havana-style building. He wears not the orange T-shirt and brown shorts of Raúl, but a guayabera, the starched Cuban linen shirt, and smart slacks. Invitingly he engages his audience:

Havana. Our dear Havana. How often have you and I asked ourselves-would we recognise Havana if we started off in any corner block, would we be able to go through her, street by street, without getting lost? We're going to find that out straight away. Sit back, enjoy a cafecito as we proceed through her. Havana now, Havana always.

Nine years later, at eleven a.m., the 28th of November 2000, Raúl, and the authors are setting out on our own tour. We leave the house in La Rampa, walk downhill past the European-style bakery, the cafe, the well stocked peso-economy bookshop to turn right at the café-bar on El Malecón. Its location is superb, its paintwork faded, its structure grey concrete, its presentation uninviting. The salt spray, Raúl tells us, is responsible for the deterioration of all these buildings of the seafront. It is clear that he will hold neither individual nor government responsible for what we are about to inspect. The building adjacent to the café-bar he identifies as a former convent though no evidence now remains of its former status. May we take a photo Raúl? Por supuesto, of course.

We take the first right again up Calle Hospital (Hospital Street), and approach that huge, light brown, aggressively modernist skyscraper intended by its 1950 s architects to 
attract its own up-market neighbourhood. The thirty stories of the hospital incongruously dominate its drab surroundings. It was to be the central bank, Raúl tells us, of which only eight stories were complete at the time of Castro's revolution. Within a month arsonist 'counter-revolutionaries' destroyed all but the shell and the secure basement which still, incongruously, holds the national treasury beside the bodies awaiting carriage to el Cementerio Colón. Past the hospital we turn up Escobar, on the threshold of what was once, fifty years ago, Havana's smartest shopping precinct. We pass the once famous factory of the Romeo y Julieta cigars. Our photo reveals the right side of the building as no more than a dirty grey front facade, three stories of gaping door frames. Trucks park on what was once the ground floor. We sense a little tension in our guide. Although we keep the camera out of sight when not in use, Raúl seems uncomfortable more at what we are photographing than at the presence of the camera itself. To us the remains of Romeo y Julieta are imposing in spite, or because, of its decay. Raúl says he will show us in the afternoon, in Old Havana, the factory of Partagás cigars which has been splendidly restored. Later we will understand why it is important to him that we see Romeo y Julieta as once it might have been. Partagás’s Real Fábrica de Tabaco, though a little larger, is similar in style and age. Its beauty after restoration, its symmetry, its breath-taking cream cement walls, its brown painted terrazas, are as astounding as Romeo y Julieta's ugliness before restoration. It is clear that Raúl wants his visitors not to judge his city as it is, but as it was, and could be again. He maintains a commentary of what the buildings used to look like. People push past in the crowded street.

Manolo Villaverde’s videoed tour begin in bright sunshine, not in Central Havana but Miramar, once one of Havana’s most exclusive residential suburbs. His camera operator is evidently crouched just above the windscreen while Manolo drives. 'These beautiful mansions ...' His mood is conspiratorial as well as nostalgic. Beneath his commentary a guitar works through a melancholy progression. 'Here we are at 26th street ...' Now a lugubrious silence settles upon the soundtrack. Few people are seen on the streets, no one is interviewed, no comment is made on the few who are seen. No-one resents the camera because nobody seems to be aware of it. Avenue after avenue unrolls past the generation of exiles metaphorically crowding the vehicle, repossessing, by their presence, the city that once was theirs. The silent road sequences acquire a dreamlike quality in which the camera, never venturing outside the car, always absorbs, never 
stops, never questions, never participates in the moment. Manolo’s constant theme remains, 'Do you remember ...?'

Raúl is remembering many times and many places. He turns into Neptuno, where the workaday commercial business of Havana still is transacted. The left hand side, where destroyed or empty buildings alternate with large but dimly lit peso-economy stores, seems to belong still to the 1950s. The right side contains most of what is left of the smarter 1950s stores, their names still picked out in ceramic floor tiles. Some, modernised, offer the latest Latin American fashions. A column of foul black smoke billows from an eye-level bakery window, so thick it seems that the place must be on fire. Raúl does not appear to notice. Like everyone else, he merely walks on the road to avoid it.

Raúl approaches the junction with Escobar, where the gold on white mosaic entrance tiles read Zapatería (shoe shop). The once high-fashion shoe store now sells massproduced items, including cheap shoes, but displays none. Windowless save for the plate glass frontage, this Zapatería was designed for creative interior flood and spot lighting, which it now lacks totally. Inside the bustling store we can dimly see twenty or thirty people moving about or queuing. Adjacent to the store crumbles to decay an abandoned three storey building. Weeds grow picturesquely from its several terrazas. Directly opposite it is the bright Tiendas Pan-Americanas furniture store, as fashionable, and as almost as expensive, as anywhere in Latin America. Raúl's eyes glisten at the rich leather sofas and glass coffee tables. It is clear that he also expects us to take a photo here. This is what his Havana ought to be.

So far we have encountered no-one except down-at-heel Havanans in the whole of the crowded precinct. Thus we are immediately noticeable and somewhat embarrassing to our guide, who clearly did not expect us to be so fascinated by ruins and decay. He is conscious of the way that Havanans are looking at him, then at us pointing the camera or staring, then back to him. His use of 'Hola hermano' (Hello brother) and 'Lo siento, hermana' (I’m sorry, sister), rather than compañero (comrade), signifies a muted personal (rather than general) apology to his countrymen and women, perhaps more for what we are photographing, rather than for our presence itself. A starving dachshund staggers past. Snap. Raúl asks us awkwardly. 'Would anyone want to take a picture of a 
healthy dog?' We try to explain, truthfully, that we take pictures of dachshunds the world over, in any condition. Raúl looks unimpressed. He suspects that we have come to gloat over the sad condition of this most elegant, most North American, Havana of the1950s. His city of memory remains one of young people and fun.

We approach Perseverancia. Of this once fashionable apartment building only the facade remains, and not much of that. It is not clear whether it has collapsed of its own weight or has been gutted. The top floor alone retains its wooden doors leading on to now vanished terrazas. A farmacia (chemist), still retains its first elegance of dark shelves and glowing bottles. One or two people stand inside buying remedies-but not aspirin, nor antibiotics nor diarrhoea mixture, which are available for dollars, not pesos, and certainly not at this store. The huge corner block opposite is also now a shell. The ground level, oddly dark in the bright sunshine, may once have been converted to shops; now it seems to be inhabited by squatters. An evidently unemployed young man in brown trousers and a pink T-shirt rolled to his shoulders watches us unmoving. Above him are two once elegant stories, now slowly crumbling. The cast iron balcony has been cut away and the corner verandah demolished, for no obvious reason. Traces of colour remain among the green-stained paint, red brick below grey cement, the blue diamondshaped ornamentation on each side of the graceful terraza. The third building is so stained with dirty green as to suggest this was its original colour. Weeds as big as small trees grow from what is left of the terrazas. Through the street-level gaping doorframes can be seen the cement ceilings stripped of timber, removed, perhaps, like the cast-iron grilles, for scrap, or to restore Old Havana. At the street level, below the green stain and the weeds, a huge hopper overflows with rubbish. A man is peering into it. Beside the hopper stands a beautifully restored Chrysler. Havanan cars seem to be in better shape than they were a decade earlier, and certainly better than the buildings. Raúl observes

And look at all these private cars in the city, you can tell which they are by their number plates. Despite our material scarcity, their owners believe in the bustling city, they drive round in it.

We ask,

Doesn't it hurt to see these ugly ruins? No, not really.

but when pressed, Raúl concedes, 
Yes, the wounds have healed but they still hurt. It's what we start with; we have no time for judgments. There's no beauty in ruins, only ugliness, but in each ruin lies the potential for restoration.

He uses the verb 'castigar' (to punish) to imply it is time which has punished the buildings, not people.

Manolo, leaving Miramar and heading down El Malecón, seems to sense danger. He tells his viewers, 'Our deepest gratitude to those people who risking more than liberty, and feigning ingenuousness under present conditions, achieved the filming of this video.' His spy-car approaches Central Havana. It begins to rain. No police, who normally stand at every corner and even now, in 2000, are watching us languidly, appear in his film. No Havanan is seen to leave any of the buildings that we are walking past, hardly anyone is seen at all. Why? Perhaps contemporary Cubans like Raúl are irrelevant to this reclamation of a single moment by a single privileged group of the city's long history. Those who remained have by implication obliterated themselves from the collective memory of the exiles whose Havana stopped in 1959 and has not yet re-started. Manolo’s Central Havana, like his memory, froze at the last moment of the old order. It is the falsity of that position that we are learning from Raúl. It is only memories which freeze, not cities.

At Amistad, Raúl guides us to the right to enter the central square of high 1950s fashion. Sydneysiders would be at the junction of Market and George St, New Yorkers, in Madison Avenue. Imagine, though, if no repairs had been made in those Sydney precincts for fifty years. Even in the bright sunshine the decrepit, boarded up department stores are depressing and a little sinister. What now can they contain? In the gloom of the upper stories, is the dirty or blackening linoleum piled with rubbish? Are the cracked and dusty counters still arranged for customers, or stacked up in corners, or have they been removed? Are the ceiling tiles falling in, the doors fallen off the changing rooms, the escalators rusted over, the lifts crashed to the bottom of shafts? What remains of the merchandise in those dusty heaps lying in every corner? Does anyone even have a key any more?

The nationalized larger stores seem parodies of what they once were. Some are trading, 
apparently only at the ground floor level. Fin De Siglo, the great and famous department store. The pale blue and white architecture of the upper stories has worn well, but water has entered the paintwork at the mezzanine level. On the street, the ubiquitous garbage hoppers, the plate glass windows timbered or papered over. Temporarily at least, Fin De Siglo, so important in the memories of Raúl and Manolo, has ceased to trade. Nearby stands the second store, La Época attacked by arsonists in April 1961 as a preliminary to the invasion at the Bay of Pigs, later rebuilt. It is again in business. Guards control the entry of the long queue outside according to the number coming out of another door. But El Encanto, the best and biggest of the three department stores, was firebombed with phosphorous and razed to the ground by the same counter-revolutionaries who destroyed the bank building, and who, Raúl tells us, were never caught. He explains that in the terrible conflagration, a female worker Fé De Valle, was killed. She’s given her name to the park where once stood the store. A sign erected to her memory reads:

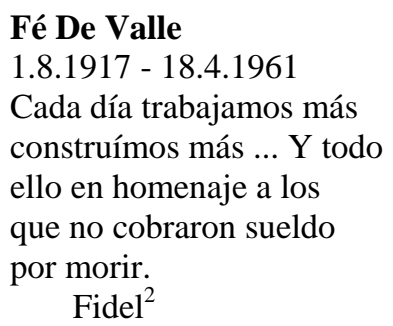

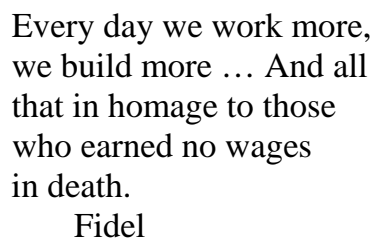

Fidel

The El Encanto park is a pleasant, well used rest area in a precinct where few others exist in this area. Even now, it retains some of the glamour of the 1950s. A large tree stands in the park, planted, presumably, as the park was constructed.

Indo-China, the brightly lit oriental clothing store, still trades on the left of Industria. Its terraza pavement, marble portico, tiled entrance and tiled store name are still intact. Snap. An elderly, modestly dressed woman stares thoughtfully into its enticing interior. She does not enter. The opposite side of the park seems not to have had a day's repairs since 1959. It looks dreadful. Raúl explains that the City Historian has not yet had time to reach the area. It is much more likely that the area will be razed rather than reconstructed as the 1950s smart Havana downtown.

By the time Manolo’s camera arrives in Central Havana, at the very street where now

\footnotetext{
${ }^{2}$ Her tomb, in Cementerio Colón, is recorded in Com-Relieve S.A. (1999: 153).
} 
we are now standing, his 1991 journey has grown darker, his filmed streets strangely melancholy. He remarks, 'That was Fin de Siglo, the shopping area of the rich.' The few people who appear on his pavements seem to walk at half the normal speed, as if in a dream. A man on a bicycle looks at and through the camera. Manolo asks his viewers nostalgically, 'Do you remember the frozen ice-cream and little sandwiches they sold at the department Store Ten Cent?' No doubt the exiles do remember, and so indeed does Raúl, and so do the older people who are buying the Cuban sandwiches and sugar cane juice here, in 2000, at this very minute. Manolo continues, 'Here’s El Arte, where many of us had our photos taken.' It's just a few metres from the fashionable men's clothing store of the 1950s, J de Valles, where Raúl bought a suit for his wedding, and outside which he is now at this moment posing. The building, still strikingly named in a running French cursive style of relief white letters on white paint, now sells cheap cotton clothes, utensils and knick-knacks. Its plate glass windows are boarded up. The glass counters have been dragged into the street from which are sold more cheap clothes. Just near here, Manolo tells his Miami viewers, was the funeral parlour, the jewellery shop, 'the store where we bought our Florsheim shoes,' the Astor movie house, the cafes, 'very memorable in our youth ... You remember, don't you?' Here was 'that very popular Chinese restaurant,' 'On the left, the old Sears.'

The few filmed Havanans of Manolo’s sunless streets never are seen to talk, work, shop, eat, touch, drink coffee, cry or laugh. They process in the streets but leave no mark upon them. They do not engage the city, nor does it engage them. Yet about us, in 2000, at this moment hundreds of people are pushing, walking about, queuing, sitting, talking, like those who throng the urban streets of the wide world. Manolo's and Raúl's Neptuno and San Rafael hardly seem to be the same streets, nor even part of the same suburb or the same city.

Manolo’s description is as evasive as Raúl's is factual. The revolution which precipitated both his own departure (and the decline of Raúl's downtown) remains absent from his commentary. Central Havana must be allowed to stay frozen; only its original beauty remains. 'Observe the natural curves of this beautiful avenue.' Throughout his film no one of the political hoardings and posters which in reality punctuate every city block are to be seen. They must have been deliberately edited out of the shot-list. Only once, in the far distance, does an image of Che Guevara appear. 
Nor does Manolo explain why the El Encanto site is now a park. Though his constituency always remains 'we,' he names no individual, identifies no one's house, visits no one’s tomb in the Cementerio Colón. Memories of families disunited, changing sides, of revolution and counter-revolution are after thirty years, still much too raw. Don't mention the Bay of Pigs. People can be edited from streets and shops. Only the 1950s endure.

Raúl's memories have by contrast moved steadily away from the 1950s. We sense some puzzlement, if not irritation, at our constant questions. 'Was that store abandoned at the time of the revolution?' He answers, or implies, 'I don’t know, I can’t remember. Why is it so important?' Life goes on, time passes, the revolution is only one reason why the city changed, and it's still changing.

We leave the park to walk the last two hundred metres down San Rafael which leads to El Prado and the Hotel Inglaterra. The Joyería Francesa, the elegant French Jewellery, looks as though it has been closed for decades, but outside, under its once grand, redpainted portico sits a woman under a beach umbrella selling watch straps and batteries. She has placed chairs on each side, one of which supports an electric fan. She seems at this moment to be doing no business. Was this the jewellery shop of Manolo's memory? A bearded man holding two plastic bags strolls past the two hoppers parked seemingly at random on the road. Bath-houses flourish in empty, or half empty, buildings. Men awaiting their turn sit on masonry blocks which seem to have tumbled from the retaining wall only yesterday. The clock outside what was once the Cine Rex, the Rex twin cinemas, the pride of Havana, now has no hands, nor motor. Almost certainly they have been removed to another location. Icons the shape of bells once marked the hours of 12, 3, 6 and 9, and what seem to be now giant buttons marked the other hours. The number five has vanished. The top row of light green tiles has fallen off the Rex - or been removed for rebuilding elsewhere? The cinema looks dark, closed off and menacing. A foul pool of sewage seeps across the road. Raúl makes no comment beyond, 'Come this way, I don't want you to get your feet wet.' A former electrical store, the European brand names still surprisingly clear, advertises above the heads of the shoppers: Hotpoint. Philips. Giralt. Almost all electrical goods imported to Cuba are now made in Asia. The store, like, seemingly almost every store in Central Havana, now sells cheap clothes and bamboo furniture. 
We cross into Avenida Bélgica which leads us to the birthplace of José Martí, a museum, though closed for the day. Raúl clearly expects us to linger at the site. We stop for granizado (flavoured shaved ice), for which he insists on paying, and reflect on what we have seen. In Raúl's city there are no ghosts, nor many precise memories, because for those who have remained the city is process, nothing remains the same, everything changes, everything will improve. Those frozen, locked-off memories of trysting places and smart shops belong to the exiles.

Yet after several hours of wandering Raúl has grown a little more sad and reflective, more for the decline of his city than for lost times. For those who have never left there is no beauty in ruins, no fascination. 'Yes, it's sad to see a lovely object wounded. But just give us time to bring in the resources, and the time to fix these things up, and we'll make the city sparkle once again. These ruins shame us more than you know.' The smashed and empty structures remind us of London during the Blitz, the cheap goods and long queues of Berlin in 1946. Raúl reminds us sharply, but obliquely, that this is a false analogy. His city was not blitzed; no one was to blame. The city has continued to change; 1959 was but a way station. Would you visit my home, his unease implies, to notice the mark on the wall, the springs protruding from the chairs? Would you move the armchair to photograph the stain on the carpet? His eyes alight in admiration of the restoration of the Museo de Bellas Artes, Raúl is the custodian of change and process, the guardian of city pride in a working city which lives and changes. Manolo is the custodian of a moment in time, of a city in snapshot.

Driving through the area nine years earlier, Manolo confines himself to the remark: 'With a little bit of imagination I'm sure that each of you can recapture the smells of petrol and the sea ... Who can forget the weatherman at the national Observatory giving the TVC weather report, "Blue skies and scattered showers across the country?”' Only those who had a TV in the 1950s.

By three in the afternoon we manage to persuade Raúl to stop for lunch at Havana's best known tourist restaurant, La Bodeguita del Medio. The meal, which would cost the average Cuban four months' salary, means little to him. He remarks that he could cook a Cuban meal better himself, and no doubt he is right. This past and present tourist area 
seems never to have been within his compass. His continuities, though not far away, are elsewhere: He used to buy clothes at Gomez de Mena, now a huge, rather ugly, dim, dusty and echoing arcade occupied only on the ground floor. The upper floors, he comments, used to be occupied by banks and businesses; it was a blaze of lights. Loppy Yu, 'the best sandwich shop in Havana,' kept going until the 1970s. La Floridita, a famous Hemingway restaurant, closed in the 1960s while the exiles established its counterpart in Miami. Now it is re-established in its first position in Zulueta Street. 'But it’s not on our map.’ Raúl explains that the boulevard was re-named Agramonte after a famous patriot of the wars of independence against Spain, but it's still called Zulueta by almost everyone, including by those born long after the revolution itself. Most of the city streets have an official and an older, unofficial name. Raúl has his own memory map of the 1950s, but one overlain and intertwined by many times, many sites, many street names, many engagements. It is one of the few attributes he shares with Manolo.

Raúl wants us to admire the restored architecture and politely scolds us for our perceived obsession with decay. We pass the Cuartel De Bomberos, the old and dilapidated fire station, now being restored as a museum. 'Why didn't you take a picture of the new and very modern fire station as well? This morning you walked straight past it. Now please admire the Centro Asturiano. Two years ago the entrance was used as a public toilet. Did you ever see a sight more magnificent than as it is now?' Indeed it is breathtakingly beautiful. Nothing froze; all is fluid. 'Things got worse, yes, which was nobody’s fault, and now they're improving.' 'El tiempo pasa,' he remarks, time passes.

Some shops closed immediately because their owners departed, some were confiscated, some were destroyed by malcontents, but most continued trading - something - for decades. Many still do. Buildings collapsed, we are assured by several people, not because we didn't look after them, but because they were not built to last and since the Special Period we have not had time to demolish them. Yet the continuous transformation of the Havanan urban space is obvious neither to the returning exiles nor to the tourists wedded to the romantic notion of the beautiful enchanted woman asleep in her neglected castle. Especially it is not obvious to that first generation of Cuban Americans who continue to imagine their city, long immobilised in briars, still awaiting the kiss of the handsome-and returning - prince. Manolo now realises that the prince will never arrive. Their city is ugly and ruined. Manolo’s purpose is to bid it farewell. 
He’s not coming back.

Shadows lengthen, and the dirty windscreen behind which his camera crouches heightens its alienation from the present. His last message is that Havana is still, beneath the rubble, beautiful; but she will never be beautiful again until the exiles return. Safe in Miami again, he addresses the camera:

You enjoyed that, didn't you? I'm sure that you have remembered forgotten places. I would bet that some of you recaptured your years as a young man there, in that very place ... Because we have all loved her. As before and as always.

The revolution froze his Central Havana. Its current population he has not mentioned once, and barely revealed it on his camera. In truth, Raúl and his countrymen and women spend their lives repairing, lamenting, queuing, admiring, engaging, waiting, and loving too; but if they are revealed without identity or solidity, or not revealed at all, they have no right to existence save as flotsam. Havana is not, to Manolo, occupied by an enemy, it is no-man's land. It is terra nullius. In his mind he will not need morally to contest the city on his triumphant return; his is the right of former possession made real by the memory of exclusive occupation. Neither a new Havana nor new Havanans have replaced the purged and exiled family, church or club. Memory triumphs over reality; memory alone is solid. It does not seem apparent to him that Raúl may have a claim upon the city at all, still less a better claim than his own.

By five thirty Raúl also has finished his tour and done with us. Towards the end, and now arrived at the area of greatest restoration, he has grown more cheerful, more accepting of the idiosyncrasies of his unusual tourists.

If Manolo had come to the city in 2000 instead of 1991, his monocular camera might have caught Raúl, and us, walking the downtown streets. Assuredly we would have been edited from the sequence, for no tourists are allowed to interrupt his flow of repossession. Perhaps Raúl alone might have been allowed to remain in shot, a humbly dressed older man, plastic bags in hand, just another Cuban who had not seen fit to leave the island at the time when the best people did so, and so paid the price. The camera could not discern that this older, stocky Havanan, was wiser now, his five decade presence redeemed by experience, by recollections both loving and bitter. And 
Manolo would not know that this man of hard and complex memory remains willing to share his city with old and new Havanans, rejoicing that the long neglect has been slowed and will soon be reversed. In truth, when Raúl thinks of exiles at all, he sees them as no more than the people who decided to leave. Pobrecitos (poor things), he calls them without irony. He does not despise Manolo or his class of exiles.

Probably the two men never met each other before 1959, and are not likely ever to do so. Yet, as Havanan males of the same age, they should have more in common than a shared affection for the old city. Manolo and Raúl occupy two different universes. Neither, though for different reasons, wants to discuss the revolution. Each year takes them further apart. El tiempo pasa.

Yet the universes can unite, with good will and understanding. Like Manolo, Miguel Bretos, a child émigré of 1961, in his case via Operation Pedro Pan, also returned many years later to Central Havana. He, too, arrived in El Encanto Park and reflected,

[The other moment of enlightenment during my return trip] was at the corner of Galiano and San Rafael. To a provincial kid, this is the Havana that mattered. El Encanto, Fin de Siglo, Flogar, Christmas shopping, matinees at the America, a bite at the Pullman before heading back across the Tunnel and the via blanca to good old Matanzas, which had none of that. It struck me that in the still unsightly, gaping void where El Encanto once stood, there rises a huge tree-forty years' worth of growth. It was a bittersweet experience: to realize how much "I" belonged there, and how much "there" belonged to me. On the other hand, in the shadow of that very tree, two generations of fellow Cubans had grown whose life experiences, thoughts, concerns and values were radically different from my own. To understand each other, we must talk to one another. And, if talk we must, that conversation must take place within a space that is physically and spiritually Cuban. (Bretos 2002)

\section{Reference List}

Castillo, Carmen (dir. and prod.) 2007, Calle Santa Fe, Agnès B. and Love Streams Productions, Paris. Chase, Graham (dir.), and Tim Read (prod.) 1987, Hellfire Pass, Film Australia, Sydney.

Com-Relieve S.A. 1999, A Guide to the Cristobal Colón Necropolis in Havana, Escudo De Oro, EEC. Bretos, Miguel A. 2002, 'Historical Cross-Pollination Through 1960: Straddling a Cultural Frontier.' ARCH: The University of Miami School of Architecture Newsletter, Summer. On line. Available: http://www.arc.miami.edu/Publications/SOANews_SprgSmmr02.pdf (accessed 28 January 2008). Riemer, Andrew 1992, Inside Outside, Angus and Robertson, Pymble, NSW.

Villaverde, Manolo (dir.) 1991, La Habana de hoy y de siempre, Ferro Video productions, Miami. 